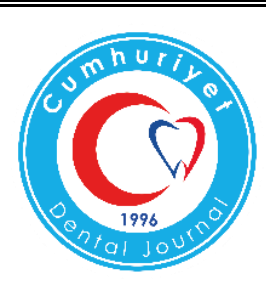

\title{
EFFECT OF SURFACE FINISHING METHODS AND AGING ON SURFACE ROUGHNESS AND OPTICAL PROPERTIES OF ZIRCONIA-REINFORCED LITHIUM SILICATE GLASS-CERAMIC
}

\begin{abstract}
Objectives: The effects of three different surface finishing methods and aging on the surface roughness and optical properties of zirconia-reinforced lithium silicate (ZLS) glass-ceramic were investigated.
\end{abstract}

Materials and Methods: Rectangular specimens ( $0.6 \mathrm{~mm}$ thickness) were sliced from ZLS blocks $(\mathrm{N}=36)$. Three different types of surface finishing [glazing combined with crystallization (ZLS-CF) or after crystallization (ZLS-G) and polishing (ZLS-P)] $(n=12)$ and 5000 thermocycles were applied. Three sets of measurements were performed before and after aging to determine the color coordinates and surface roughness ( $\mathrm{Ra}$ ) by using a colorimeter and profilometer, respectively. The mean surface roughness $(\mathrm{Ra})$ values were calculated. Color differences and translucency parameter (TP) values were calculated using the color difference $\Delta \mathrm{E}_{\mathrm{ab}}$ and TP formulas. One-way ANOVA was used to analyze the color difference, translucency, and surface roughness values $(\alpha=.05)$.

Results: Significant differences in the $\Delta \mathrm{E}$ values were not observed $(\mathrm{p}=.736)$ for specimens with different types of surface finishing. A significant difference was observed between the translucency values for different surface finishing groups before aging $(\mathrm{p}<.001)$. A significant difference in the surface roughness data between samples with different kinds of surface finishing was observed both before and after aging $(\mathrm{p}<.001)$. The ZLS-P group exhibited lowest surface roughness values before and after aging $(\mathrm{p}<.001)$. A positive significant correlation between the $\Delta \mathrm{E}$ and translucency change values was observed in both the ZLS-G ( $\mathrm{p}=.005)$ and ZLS-P ( $\mathrm{p}<.001)$ groups.

Conclusions: The surface finishing type did not affect the color change of ZLS glass-ceramic. The translucency values for different surface finished ZLS glassceramic specimens changed before aging. After aging, the surface finishing did not affect the translucency of ZLS glass-ceramic. All tested groups exhibited surface roughness values higher than the plaque accumulation threshold $(\mathrm{Ra}=0.2 \mathrm{~mm})$.

Keywords: Ceramics, color, surface properties
ORCID IDs of the authors:

0000-0003-1751-9207

0000-0002-2510-9745

${ }^{1}$ Department of Prosthetic Dentistry, Faculty of Dentistry, Istanbul Okan University, İstanbul Turkey.

${ }^{2}$ Department of Prosthetic Dentistry, Faculty of Dentistry, Kütahya Sağlık Bilimleri University, Kütahya, Turkey.

Received : 25.12 .2018

Accepted : 26.02.2019

How to Cite: Alp G, Subaşı GM. Effect of Surface Finishing Methods and Aging on Surface Roughness and Optical Properties of Zirconia-Reinforced Lithium Silicate

Glass-Ceramic. Cumhuriyet Dent J 2019;22:1:121-130.

*Corresponding Author

Istanbul Okan Üniversitesi Diş Hekimliği Fakültesi Protetik Diş Tedavisi ABD Tuzla Yerleşkesi, Akfirat Tuzla Istanbul, Turkey.

Phone: +90 5054538813 E-mail: gulce165@ hotmail.com 


\section{INTRODUCTION}

Clinical selection of appropriate restoration material is essential for ensuring clinical success. ${ }^{1}$ Monolithic computer-aided design and computeraided manufacturing (CAD-CAM) materials are presented to satisfy demand for esthetically acceptable restorations with better optical and physical properties. ${ }^{2-4}$ Zirconia, glass ceramics (feldspathic, lithium disilicate, and zirconiareinforced lithium silicate), and ceramic/glass polymer materials are some monolithic CADCAM materials that are currently available. ${ }^{4}$

Among these materials, zirconia-reinforced lithium silicate glass-ceramic (ZLS) was introduced as a novel monolithic CAD-CAM material for the construction of crowns, implant suprastructures, inlays, and onlays. ${ }^{5-7}$ Currently, two different ZLS glass-ceramics (VITA Suprinity PC and Celtra Duo) are available with different sizes of lithium metasilicate crystals. ${ }^{8}$ Both of these ZLS glass-ceramics claimed to combine the optical properties of glass ceramics (56-64\% silica content) and mechanical properties of zirconia (8-14\% zirconia content) ${ }^{5,8,9}$ These materials have a fine-grained $(0.5-0.7 \mu \mathrm{m})^{5}$ and uniform microstructure ${ }^{10}$ with characteristic needle-shaped crystals. ${ }^{11}$ The crystal phase content of ZLS glass-ceramics (40-50\%) is lower than that in lithium disilicate glass ceramic $(70 \%) .^{12,13}$ In addition, these materials have optical and physical properties that are comparable to those of lithium disilicate ${ }^{12,13}$ and fulfill the esthetic requirements through their enhanced translucency and different shade options. $^{11}$

The roughness, smoothness and surface quality of a restoration material is important for ensuring a desired esthetic appearance and longterm clinical succes ${ }^{14,15}$ because rough surfaces have an impact on discoloration ${ }^{16}$, shade matching ${ }^{17}$, plaque accumulation, wear against opposite restoration materials or teeth, ${ }^{18}$ and the tactile perception of the patient. ${ }^{19}$ Well-finished surfaces were reported to cause fewer technical and esthetic problems by providing the material with tougher, glossier, and more stable translucency ${ }^{3}$ and color. ${ }^{20,21}$ In addition, the light reflects and diffuses from an irregular and rough surface, which alters the restoration color. ${ }^{22}$ The surface roughness of the restoration materials is affected by different factors and conditions. ${ }^{17,18} \mathrm{~A}$ clinically acceptable $\mathrm{Ra}$ threshold for prostheses was reported to be $0.2 \mu \mathrm{m} .{ }^{23}$ Excessive microbial adhesion and plaque formation occur when $\mathrm{Ra}>0.2$ $\mu \mathrm{m} .^{23}$

Optical characteristics like color stability, translucency, and opalescence must be considered during the selection of materials for maintaining esthetics. $^{6,24}$ The optical characteristics of restoration materials were reported to be affected by the material structure and surface texture, thickness, material and background shade, manufacturing technique, luting agent, ${ }^{24,25}$ and aging. ${ }^{26}$ Color changes throughout the functional lifetime negatively affect the survival and quality of restorations, ${ }^{27}$ thus restoration materials must be stain resistant for long-term use. ${ }^{15}$ Optimal translucency is also required for the restorations to provide a natural appearance and the desired esthetic outcome. ${ }^{3,28}$ Knowledge of the translucency of restoration materials is clinically important, especially when rehabilitating discolored teeth. ${ }^{28}$ Therefore, knowledge of the translucency and color stability of ZLS glassceramic is required in order to achieve clinical success. ${ }^{3,28}$

Restoration surfaces can be finished by using various glazing and polishing techniques. ${ }^{15}$ Although manufacturers recommend different glazing procedures combined with crystallization or after crystallization and polishing for ZLS glass-ceramics, it is uncertain whether glazing combined with crystallization or after crystallization or polishing provide more appropriate color stability, translucency, and surface roughness. Therefore, this study aimed to evaluate the effects of three different surface finishing methods (glazing combined with crystallization or after crystallization and polishing) and aging on the surface roughness, color stability, and translucency of ZLS glassceramic. The first null hypothesis was that the type of surface finishing would not affect the color stability of ZLS glass-ceramic. The second 
null hypothesis was that the type of surface finishing, and aging would not affect the translucency of ZLS glass-ceramic. The third null hypothesis was that the type of surface finishing and aging would not affect the surface roughness of ZLS glass-ceramic.

\section{MATERIALS AND METHODS}

The color stability, translucency, and surface roughness values of zirconia-reinforced lithium silicate glass-ceramic (Vita Suprinity PC, VITA Zahnfabrik, Bad Sackingen, Germany) (ZLS) (Table 1) $(\mathrm{N}=36)$ were evaluated before and after aging.

Table 1. Materials used

\begin{tabular}{|c|c|c|c|c|}
\hline Material & Code & Manufa & cturer & Lot No. \\
\hline VITA Suprinity PC & ZLS & $\begin{array}{l}\text { VITA } \\
\text { Bad } \\
\text { Germany }\end{array}$ & $\begin{array}{l}\text { Zahnfabrik, } \\
\text { Sackingen, }\end{array}$ & 36851 \\
\hline $\begin{array}{l}\text { VITA AKZENT } \\
\text { Plus GLAZE LT }\end{array}$ & GLZ-P & $\begin{array}{l}\text { VITA } \\
\text { Bad } \\
\text { Germany }\end{array}$ & $\begin{array}{l}\text { Zahnfabrik, } \\
\text { Sackingen, }\end{array}$ & 51800 \\
\hline $\begin{array}{l}\text { VITA AKZENT } \\
\text { Plus GLAZE LT } \\
\text { SPRAY }\end{array}$ & GLZ-S & $\begin{array}{l}\text { VITA } \\
\text { Bad } \\
\text { Germany }\end{array}$ & $\begin{array}{l}\text { Zahnfabrik, } \\
\text { Sackingen, }\end{array}$ & E65960 \\
\hline $\begin{array}{l}\text { VITA SUPRINITY } \\
\text { Polishing Set } \\
\text { Technical }\end{array}$ & POL & $\begin{array}{l}\text { VITA } \\
\text { Bad } \\
\text { Germany }\end{array}$ & $\begin{array}{l}\text { Zahnfabrik, } \\
\text { Sackingen, }\end{array}$ & E42530 \\
\hline
\end{tabular}

ZLS: zirconia-reinforced lithium silicate glass-ceramic.

ZLS glass-ceramic blocks were sliced into rectangular specimens $(0.6 \pm 0.03 \mathrm{~mm}$ in thickness $)$ under water (Vari/cut VC-50, Leco Corporation, St Josephs, MI, USA). According to the manufacturer's advice, the specimens were cleaned (15 minutes) with distilled water (Sultan 600 ProSonic 600-MTH, Mexico) in an ultrasonic cleaning device and dried. The specimens were then separated in three surface finishing groups: Group 1: glazing combined with crystallization (ZLS-combination firing, ZLS-CF), Group 2: glazing after crystallization (ZLS-glazed, ZLS-G), and Group 3: polishing (ZLS-polished, ZLS-P). All surface finishing procedures were applied to the top surface of each specimen by the same operator (G.A.).

ZLS-CF group ( $\mathrm{n}=12)$ : Glaze spray (VITA AKZENT Plus GLAZE LT SPRAY, VITA Zahnfabrik, Bad Sackingen, Germany) was shaken thoroughly before being applied to each specimen and was sprayed on the top surface of the specimens at a distance of $10-15 \mathrm{~cm}$ as a single layer, according to the manufacturer's recommendations. Combination firing was subsequently performed (Programat P310, Ivoclar Vivadent AG, Liechtenstein, Austria) $\left(840{ }^{\circ} \mathrm{C}, 8\right.$ minutes).

ZLS-G group $(\mathrm{n}=12)$ : These specimens were fully crystallized (Programat P310, Ivoclar Vivadent AG, Liechtenstein, Austria) $\left(840{ }^{\circ} \mathrm{C}, 8\right.$ minutes). After crystallization firing, glaze material (VITA AKZENT Plus Glaze LT powder, VITA Zahnfabrik, Bad Sackingen, Germany) was applied as a single thin layer and glaze firing was performed $\left(800^{\circ} \mathrm{C}, 60\right.$ seconds).

ZLS-P group $(\mathrm{n}=12)$ : These specimens were fully crystallized (Programat P310, Ivoclar Vivadent AG, Liechtenstein, Austria) $\left(840{ }^{\circ} \mathrm{C}, 8\right.$ minutes). The specimens were then manually polished with a handpiece at slow-speed using recommended 2-stage (pink and gray) diamondcoated laboratory polishing burs (VITA Suprinity Polishing Set Technical, VITA Zahnfabrik, Bad Sackingen, Germany). First, the specimens were pre-polished with a pink assortment (10000 rpm) and then polished with a gray assortment (7000 rpm) to produce higher gloss. All polishing assortments were handled in one direction under mild force.

A caliper (Model number NB60; Mitutoyo American Corporation, Providence, RI, USA) was used to measure the ultimate thickness of each ZLS specimen. Afterwards, the specimens were kept in distilled water $\left(37^{\circ} \mathrm{C}\right)$ for 24 hours before measuring the baseline color and surface roughness. Baseline color measurements were gathered using the color parameters acquired from the CIELab (Commission Internationale De L'éclairage $\mathrm{L}^{*}, \mathrm{a}^{*}, \mathrm{~b}^{*}$ ) color space relating to D65 CIE illumination and CIE Standard Human Observer $\left(2^{\circ}\right)$ with a colorimeter (Minolta CR 321, Konica Minolta, Tokyo, Japan).$^{29} \mathrm{~L}^{*}$, a*, and $b^{*}$ values were measured on two different backings. The CIE values were $L^{*}=19.74$, $a^{*}=-$ 0.78 , and $b^{*}=0.11$ on a black backing and the CIE values were $\left.L^{*}=78.02, a^{*}=-6.0, b^{*}=-0.5\right)$ on a white backing for wavelengths ranging from 400 to $700 \mathrm{~nm}^{30}$ The colorimeter was calibrated before gathering measurements for each specimen (CIE L* $=93.05, a^{*}=-4.85$, and $b^{*}=6.95$ ), and the color measurements were gathered from the 
middle of each ZLS specimen. Measurements were repeated three times consecutively for each ZLS specimen, and the average $\mathrm{L}^{*}, \mathrm{a}^{*}$, and $\mathrm{b}^{*}$ values were recorded.

The color difference $(\Delta \mathrm{E})$ for each ZLS specimen on the white backing after aging was calculated using the following CIELab formula: ${ }^{29}$

$\Delta \mathrm{E}_{\mathrm{ab}}=\left[\left(\Delta \mathrm{L}^{*}\right)^{2}+\left(\Delta \mathrm{a}^{*}\right)^{2}+\left(\Delta \mathrm{b}^{*}\right)^{2}\right]^{1 / 2}$

$\Delta \mathrm{L}^{*}, \Delta \mathrm{a}^{*}$, and $\Delta \mathrm{b}^{*}$ represent the difference in lightness or darkness, red-green axis, and yellow-blue axis, respectively.

The color difference values over a black and a white backing were used in the following equation to calculate the translucency parameter (TP) $:^{31}$

$\mathrm{TP}=\left[\left(\mathrm{L}_{\mathrm{B}} *-\mathrm{Lw}_{\mathrm{w}} *\right)^{2}+\left(\mathrm{a}_{\mathrm{B}} *-\mathrm{aw}_{\mathrm{w}} *\right)^{2}+\left(\mathrm{b}_{\mathrm{B}} *-\mathrm{b}_{\mathrm{w}} *\right)^{2}\right]^{1 / 2}$

$\mathrm{B}$ represented the color coordinates over a black backing and $\mathrm{W}$ represented the color coordinates over a white backing.

Ultrasonic cleaning was applied again (Sultan 600 ProSonic 600-MTH, Mexico) (10 minutes) before gathering surface roughness measurements. The surface roughness was measured 3 times for all specimens with a contact profilometer (Mitutoyo Surftest SV-2100, Mitutoyo Corporation, Minatoku, Japan) after calibration (5.5 mm tracing length, $0.8 \mathrm{~mm}$ cut-off length, and $1 \mathrm{~mm} / \mathrm{s}$ stylus speed). The average Ra values were calculated. ${ }^{32}$

Following baseline color and surface roughness measurements, an aging procedure consisting of 5000 thermocycles was applied to all ZLS specimens (MTE-101, Moddental, Esetron Smart Robotecnologies, Ankara, Turkey; distilled water, $5{ }^{\circ} \mathrm{C} / 55{ }^{\circ} \mathrm{C}$, 30 seconds dwell duration, 10 seconds bath transfer duration). ${ }^{6}$ Color, translucency, and surface roughness measurements were gathered again for all ZLS specimens after thermocycling.

The color difference, translucency, and surface roughness values were analyzed statistically (SPSS Statistics for Windows v17.0, IBM SPSS Statics, New York, USA). The color difference values, translucency, and surface roughness were analyzed using the one-way analysis of variance (ANOVA). Post-hoc analysis was computed with Tukey's honest significant difference (HSD) test. Correlations between color difference, translucency, and surface roughness values were computed using Spearman correlation analysis $(\alpha=.05)$.

\section{RESULTS}

According to the 1-way ANOVA results (Table 2), no statistically significant difference was observed between the $\Delta \mathrm{E}$ values for two different surface finishing groups $(\mathrm{p}=.736)$.

Table 2. $\Delta \mathrm{E}$ values for groups with different types of surface finishing

\begin{tabular}{|c|c|}
\hline Group & Mean \pm SD \\
\hline ZLS-G & $2.90 \pm 1.56^{\mathrm{a}}$ \\
\hline ZLS-P & $3.04 \pm 1.45^{\mathrm{a}}$ \\
\hline ZLS-CF & $3.43 \pm 2.01^{\mathrm{a}}$ \\
\hline$P$ (1-way ANOVA) & .736 \\
\hline \multicolumn{2}{|c|}{$\begin{array}{l}\text { ZLS: zirconia-reinforced lithium silicate glass-ceramic, ZLS-G } \\
\text { ZLS-glazed, ZLS-P: ZLS-polished, ZLS-CF: ZLS-combination } \\
\text { firing, SD: Standard deviation. Superscripts indicate that there is no } \\
\text { significant difference between groups }(p>.05) \text { based on 1-way } \\
\text { ANOVA results. }\end{array}$} \\
\hline
\end{tabular}

According to the 1-way ANOVA results (Table 3 ), there was a statistically significant difference between the translucency values for groups with different types of surface finishing before aging $(\mathrm{p}<.001)$, whereas there was no statistically significant difference between the translucency values for groups with different types of surface finishing after aging ( $\mathrm{p}>$.05).

Table 3. Translucency values for groups with different types of surface finishing

\begin{tabular}{|c|c|c|c|}
\hline Group & $\begin{array}{l}\text { Before } \\
\text { aging } \\
\text { Mean } \pm \text { SD }\end{array}$ & $\begin{array}{l}\text { After aging } \\
\text { Mean } \pm \text { SD }\end{array}$ & $p^{*}$ \\
\hline ZLS-G & $9.23 \pm 2.50^{\mathrm{a} 1}$ & $\begin{array}{l}10.37 \\
\pm 0.80^{\mathbf{a} 1}\end{array}$ & .182 \\
\hline ZLS-P & $\begin{array}{l}12.98 \\
\pm 0.59^{\mathbf{b} 1}\end{array}$ & $\begin{array}{l}10.49 \\
\pm 1.12^{\mathrm{a} 2}\end{array}$ & .002 \\
\hline ZLS-CF & $7.83 \pm 1.45^{\mathrm{a} 1}$ & $\begin{array}{l}11.55 \\
\pm 2.54^{\mathrm{a} 2} \\
\end{array}$ & .002 \\
\hline $\begin{array}{l}\mathrm{p} \quad \text { (1-way } \\
\text { ANOVA) }\end{array}$ & .000 & .177 & \\
\hline \multicolumn{4}{|c|}{$\begin{array}{l}\text { ZLS: zirconia-reinforced lithium silicate glass-ceramic, ZLS-G: } \\
\text { ZLS-glazed, ZLS-P: ZLS-polished, ZLS-CF: ZLS-combination } \\
\text { firing, SD: Standard deviation. Different superscript numbers in the } \\
\text { same row and different superscript letters in same column indicate } \\
\text { significant differences between the surface finish values in these } \\
\text { groups }(p<.05) \text { based on 1-way ANOVA results. "Wilcoxon test. }\end{array}$} \\
\hline
\end{tabular}


The ZLS-P group exhibited statistically significant higher translucency values than the ZLS-G and ZLS-CF groups $(p<.001)$ before aging. The translucency values of the aged and unaged samples were compared; the ZLS-P group showed statistically lower translucency values after aging $(\mathrm{p}=.002)$, whereas the ZLS-CF group showed statistically significant higher translucency values after aging $(\mathrm{p}=.002)$.

According to the 1-way ANOVA results, a statistically significant difference between the surface roughness values for groups with different kinds of surface finishing was observed before and after aging $(\mathrm{p}<.001)$ (Table 4). The ZLS-P group exhibited statistically significant lower surface roughness values than the ZLS-G and ZLS-CF groups before and after aging $(p<.001)$. Regarding surface roughness, the ZLS-G ( $p=.003$ ) and ZLS-CF ( $\mathrm{p}=.017)$ groups showed statistically significantly higher surface roughness values after aging.

Table 4. Surface roughness $(\mu \mathrm{m})$ values for groups with different types of surface finishing

\begin{tabular}{|c|c|c|c|}
\hline Group & $\begin{array}{l}\text { Before aging } \\
\text { Mean } \pm \text { SD }\end{array}$ & $\begin{array}{l}\text { After aging } \\
\text { Mean } \pm \text { SD }\end{array}$ & $p^{*}$ \\
\hline ZLS-G & $0.78 \pm 0.16^{\mathbf{b} 1}$ & $0.93 \pm 0.13^{\mathbf{b} 2}$ & .003 \\
\hline ZLS-P & $0.27 \pm 0.08^{\mathrm{a} 1}$ & $0.33 \pm 0.14^{\mathrm{a} 1}$ & .266 \\
\hline ZLS-CF & $0.64 \pm 0.31^{\mathbf{b} 1}$ & $0.73 \pm 0.34^{\mathbf{b} 2}$ & .017 \\
\hline $\begin{array}{ll}\mathrm{p} & \text { (1-way } \\
\text { ANOVA) }\end{array}$ & .000 & .000 & \\
\hline \multicolumn{4}{|c|}{$\begin{array}{l}\text { ANOVA) } \\
\text { ZLS: zirconia-reinforced lithium silicate glass-ceramic, ZLS-G: } \\
\text { ZLS-glazed, ZLS-P: ZLS-polished, ZLS-CF: ZLS-combination } \\
\text { firing, SD: Standard deviation. Different superscript numbers in the } \\
\text { same row and different superscript letters in same column indicate } \\
\text { significant differences between the surface finish values in these } \\
\text { groups }(p<.05) \text { based on 1-way ANOVA results. "Wilcoxon test. }\end{array}$} \\
\hline
\end{tabular}

With respect to the Spearman correlation analysis results, a positive significant correlation was observed between the $\Delta \mathrm{E}$ and translucency change values (before and after aging) for the ZLS-glazed $(p=.005)$ and ZLS-polished $(p<.001)$ groups. No significant correlation was observed between the $\Delta \mathrm{E}$ and roughness change values (before and after aging) and between the translucency (before and after aging) and roughness changes (before and after aging) in all groups (p>.05).

\section{DISCUSSION}

The first null hypothesis was accepted because the type of surface finishing (glazing combined with crystallization or after crystallization and polishing) had no significant effect on the color differences $(\mathrm{p}=.736)$. ZLS glass-ceramic contains 56\%-64\% glass content, which did not change after crystallization. ${ }^{24} \mathrm{~A}$ possible explanation for not finding color differences is the color stability of the material with different types of surface finish, which can be attributed to the homogenous, fine crystalline structure of crystallized ZLS. ${ }^{6}$

The type of surface finishing affected the translucency values before aging $(\mathrm{p}<.001)$, and the ZLS-P group presented the highest translucency values $(p<.001)$. The translucency values for the ZLS-P group significantly decreased after aging $(p=.002)$, whereas the values for the ZLS-CF group significantly increased after aging $(\mathrm{p}=.002)$. Therefore, the second null hypothesis was rejected. In the ZLS-G $(p=.005)$ and ZLS-P $(\mathrm{p}<.001)$ groups, a positive, statistically significant correlation between the $\Delta \mathrm{E}$ and translucency change values (before and after aging) was observed. The difference in TP values due to glazing and polishing may be due to the glaze material and its application. Although controversial results were reported in the literature, the glaze material was reported to affect the TP and $\Delta \mathrm{E}$ values. ${ }^{15}$ In addition, the number of firings was reported to affect the TP and CIELab values. ${ }^{33}$ In the present study, the specimens (except the ZLS-G group) were fired once. Although there was some difference in the number of firings, microstructure, grain size, and chemical composition among the glaze materials, no significant difference between the ZLS-CF and ZLS-G groups was observed in terms of the TP values before and after aging.

The type of surface finishing affected the surface roughness values before and after aging $(\mathrm{p}<.001)$. ZLS-P group presented the lowest surface roughness values before and after aging $(p<.001)$. The surface roughness values of the ZLS-G ( $\mathrm{p}=.003)$ and ZLS-CF ( $\mathrm{p}=.017)$ groups significantly increased after aging. Therefore, the third null hypothesis was rejected.

Fully crystallized ZLS glass-ceramics can be cemented after milling and glazing or polishing, 
whereas pre-crystallized ZLS glass-ceramics require a further crystallization firing process combined with glazing, additional glazing, or polishing to reach its final esthetic and physical properties. ${ }^{34}$ Studies reported in the literature investigated the surface characteristics and optical properties (glazing or polishing) of ZLS glassceramics. ${ }^{6,11}$ However, data on the glazing efficiency with or without crystallization are limited. ${ }^{6}$ Therefore, this study proposed that the effect of the combined firing process be evaluated.

Alp et $a l .{ }^{6}$ reported clinically acceptable color differences (<CIEDE2000 50\% acceptability threshold, 1.8 units) for different surface-finished (glazing or polishing) ZLS glass-ceramics after coffee thermocycling. Kilinc and Turgut ${ }^{15}$ also reported clinically acceptable color changes in ZLS glass-ceramics regardless of the type of surface finishing (control, manual polishing, or glazing). In parallel with these studies, the type of surface finishing did not affect the color change results in this study. The color change values were below the clinically acceptable limit for all groups $\left(<3.7 \Delta\right.$ E units). ${ }^{35}$ In addition, Kilinc and Turgut ${ }^{15}$ reported that manual polishing techniques could produce similar results as glazing in terms of color stability, in parallel with the present study. In the light of these studies, ${ }^{6,15}$ glazing combined with crystallization or after crystallization and polishing may be the surface finishing method of choice for ZLS glass-ceramics because all groups exhibited similar color changes.

Although translucency has clinical importance in the esthetics and natural appearance of restoration materials, ${ }^{3,36}$ few studies have investigated TP values for ZLS glass-ceramic. ${ }^{3}$ Sen et al. ${ }^{28}$, Awad et al. ${ }^{3}$, and Caprak et al. ${ }^{37}$ evaluated the TP values for different CAD-CAM materials; Vita Suprinity (ZLS) showed the highest TP values in all of these studies. According to Awad et al. ${ }^{3}$, better TP values for ZLS ceramic might be due to the high glass content that results from smaller silicate crystals in the lithium silicate glassy matrix. ${ }^{3}$ Bahgat et $a l .{ }^{38}$ reported that the higher translucency of ZLS glass-ceramic might be due to its lower $(0.5 \mu \mathrm{m})$ and more homogeneous crystalline structures $(2$ types). Riquieri et $a l^{34}$ also reported many differences in the microstructure of ZLS glassceramics before and after crystallization firing; zirconia grains decreased and nanocrystalline lithium metasilicate peaks $\left(\mathrm{Li}_{2} \mathrm{SiO}_{3}\right)$ were more intense in $\mathrm{X}$-ray diffraction after the crystallization firing process (CFP). Although microstructural differences in the ZLS glassceramic were not evaluated in the present study, the difference in TP values may be due to microstructural changes in the ZLS glass-ceramic and the glazing materials during firing. According to previously published research, the durability of glaze materials was suspected, ${ }^{39}$ and different glaze materials like glazing spray were less effective at smoothing the surfaces because they were to unable to uniformly coat all surface irregularities. ${ }^{40}$

Alp et al. ${ }^{6}$ reported that the type of surface finishing did not affect the translucency of ZLS, whereas coffee thermocycling reduced the translucency. Even though the clinical effect of this difference was unclear, the translucency of the ZLS-P and ZLS-CF groups changed after aging in the present study, in parallel with Alp et al's ${ }^{6}$ study. In contrast, the type of surface finishing had an effect on TP before aging in the present study.

Subasi et al $^{41}$ reported that color changes in ZLS glass-ceramic were significantly affected by its thickness $(0.5,0.7$, and $1 \mathrm{~mm})$, and ZLS glassceramic with $0.5 \mathrm{~mm}$ thickness exhibited unacceptable color changes (>CIEDE2000 50\% acceptability threshold, 1.8 units). In contrast with the present study, the translucency was not affected by coffee thermocycling, whereas it was affected by material type and thicknesses; translucency decreased when the thickness of the material increased. Gunal and Ulusoy ${ }^{24}$ also reported that different thicknesses $(0.5$ and $1 \mathrm{~mm})$ of ZLS ceramic presented statistically significant differences in translucency, and the reduced thickness resulted in a significant increase in translucency. In the present study, the thickness of ZLS was $0.6 \mathrm{~mm}$ and thermocycling was applied in distilled water. The difference between color changes and the TP values in the present study 
and previous studies ${ }^{24,41}$ might arise due to differences in the thickness of the ZLS material, different aging solutions, and different color measuring devices.

According to the manufacturer, zirconia dioxide particles in ZLS glass-ceramics provide good surface finishing and reinforce the ceramic structure by providing crack interruption through its small grains and homogeneously distributed structure. ${ }^{11}$ Although various techniques and systems have been used to produce smooth ceramic surfaces, there is no standard protocol for optimal surface treatment of ZLS glass-ceramic ${ }^{41}$, and conflicting results were reported in previous studies. It was repeatedly reported that the surface finishing ${ }^{17}$, polishing, or glazing quality affect the surface roughness of ceramic materials differently. ${ }^{21}$

Vichi et $\mathrm{al}^{21}$ evaluated the efficiency of different manual and furnace-based finishing systems on surface roughness and gloss of VITA Suprinity and IPS e.max CAD by applying glazing or polishing using the manufacturer's recommended polishing sets for 30 and 60 seconds, as well as paste and spray glaze materials. The researchers reported that polishing and glazing produced similar results with regard to roughness. However, lower roughness and higher gloss were produced in paste glazing than with spray glazing, and the polishing time affected the roughness. In contrast, no significant difference was found between surface roughness values of ZLS-CF and ZLS-G groups in the present study, in which glaze spray and powder were used, respectively. The ZLS-P group in the present study exhibited the lowest surface roughness values. This might be due to the higher content of zirconium dioxide, which was shown to allow the material to provide more effective polishing. ${ }^{42}$ In addition, the type of surface finishing significantly affected the surface roughness of the ZLS glass-ceramic, and the surface roughness values increased with aging in the present study.

In contrast to the present study, Mota et al. ${ }^{43}$ reported that glazed surfaces were smoother than polished surfaces based on their SEM and AFM images, and they recommended glazing after mechanical polishing for ZLS glass-ceramic. However, in parallel with the study of Vichi et $a l .{ }^{21}$, the mean surface roughness values were higher than the $0.2 \mu \mathrm{m}$ thresholds, regardless of the type of surface finish. The ZLS-P group showed the lowest surface roughness values before and after aging, thus polishing may be preferred to glazing.

Different types of surface finishing were selected to mimic clinical conditions because there is no standard surface finishing procedure for ZLS glass-ceramic, and the manufacturer recommend all of these surface finishing procedures. The color change, translucency, and surface roughness of ZLS glass-ceramic were evaluated in this study, because all of these factors have an important effect on the esthetic success of a ceramic restoration. ${ }^{41}$ Color values of ZLS material were measured using a colorimeter. A colorimeter is frequently used to measure $\Delta \mathrm{E}$ values $^{44}$, but an edge-loss effect can be seen. ${ }^{45}$ Similar to the study of Gürdal et al. ${ }^{46}$, color changes and surface roughness were evaluated following 5000 thermocycles in distilled water, which corresponds to 6 months of aging. ${ }^{47}$

One of the limitations of the present study was that optical properties and surface roughness of ZLS glass-ceramic were not evaluated after coffee thermocycling. The coffee thermocycling might have a different effect on the color change of ZLS glass-ceramic. The color change of ZLS glass-ceramic may have been different from what can be observed in clinical conditions because no staining solution was used. The other limitation was that only one thickness was evaluated. One should recall that different thicknesses might also affect the color and translucency of the restoration. The third limitation was that the specimens were flat and no cementation procedure was applied. Color changes can be perceptible when cementation is applied. However, the effect of resin cements and underlying tooth color on the optical properties of ZLS glass-ceramic are other topics that should be investigated in further research. 


\section{CONCLUSIONS}

The surface finishing type did not affect the color change of zirconia-reinforced lithium silicate glass-ceramic. The translucency values of zirconia-reinforced lithium silicate glass-ceramic with different types of surface finishing changed before aging, whereas after aging the type of surface finishing did not affect the translucency of zirconia reinforced lithium silicate glass-ceramic. The ZLS-CF group exhibited the lowest translucency values before aging, whereas this group exhibited the highest translucency values after aging. ZLS-P group exhibited the lowest surface roughness values, regardless of aging. The surface roughness values were higher than the plaque accumulation threshold $(0.2 \mu \mathrm{m})$, regardless of the type of surface finish.

\section{ACKNOWLEDGEMENTS}

VITA Zahnfabrik are gratefully acknowledged for supplying the materials used in this study.

\section{FUNDING}

The authors do not have any financial interest in the companies whose materials are included in this article.

\section{CONFLICT OF INTEREST}

None.

\section{Yüzey Bitirme İşlemlerinin ve Yaşlandırmanın Zirkonya ile Güçlendirilmiş Lityum Silikat Cam- Seramik Materyalinin Optik Özellik ve Pürüzlülü̆ğ̈̈ Üzerindeki Etkileri}

\section{$\ddot{O} Z$}

Amaç: Bu çalı̧̧manın amacı üç farkll yüzey bitirme yönteminin ve yaşlandirmanin, zirkonya ile güçlendirilmiş lityum silikat (ZLS) cam-seramiğin yüzey pürüzlülüğ̈̈ ve optik özellikleri üzerindeki etkilerini araştırmaktır. Gereç ve Yöntemler: Dikdörtgen şeklindeki örnekler (0,6 mm kalınlıkta) ZLS bloklardan $(N=36)$ kesildi. $\ddot{U}_{c ̧}$ farkl tipte yüzey bitirme işlemi [kristalizasyon ile birlikte glazür (ZLS-CF), kristalizasyon sonrast glazür (ZLS-G) ve polisaj (ZLS-P)] $(n=12)$ ve 5000 termal siklus uygulandi. Yaşlandirma öncesi ve sonrasinda üçer defa renk koordinatlarl ve yӥzey pürüzlülü̆̆̈̈ (Ra) ölçümleri kolorimetre ve profilometre cihazları kullanilarak yapıldı. Ortalama yӥzey pürüzlülüğ̈̈ $(R a)$ değerleri hesaplandl. Renk farklllkklarl ve translusensi parametresi (TP) değerleri, $\Delta E_{a b}$ renk farklllğ̆ ve TP formülleri kullanılarak hesaplandl. Renk farkl, translusensi ve yüzey pürüzlülük değerlerini analiz etmek için tek-yönlü ANOVA kullanild $(\alpha=, 05)$. Bulgular: Farkll yüzey bitirme tiplerine sahip örneklerde $\Delta E$ değerlerinde anlaml farkliliklar gözlenmedi ( $p=, 736)$. Yaşlandirma öncesinde farkl tipteki yüzey bitirme gruplarında translusensi değerleri arasinda anlaml fark gözlendi $(p<, 001)$. Yaşlandirma öncesi ve sonrasinda farkl tipteki yüzey bitirme gruplarnda yüzey pürüzlülüğ̈̈ verilerinde anlaml fark gözlendi (p<,001). ZLS-P grubu yaşlandırma öncesi ve sonrası en düşük yüzey pürüzlülüğü değerlerini gösterdi $(p<, 001)$. Hem ZLS-G (p=,005) hem de ZLS-P $(p<, 001)$ gruplarında $\triangle E$ ve translusensi değişim değerleri arasinda pozitif yönde anlamlı bir korelasyon bulundu. Sonuçlar: Yüzey bitirme tipi ZLS cam-seramiğin renk değişimini etkilemedi. Farkl yüzey bitirme işlemi uygulanan ZLS cam-seramik örneklerinde translusensi değerleri yaşlandırmadan önce değişirken, yaşlandırmadan sonra yüzey bitirme tipi ZLS camseramiğin translusensisini etkilemedi. Test edilen tüm gruplar, plak akümülasyon eşik değerinden daha yüksek yüzey pürüzlülüğ̈̈ değerleri sergiledi (Ra=0,2 mm). Anahtar Kelimeler: Seramikler, renk, yüzey özellikleri.

\section{REFERENCES}

1. Preis V, Hahnel S, Behr M, Bein L, Rosentritt M. In-vitro fatigue and fracture testing of CAD/CAMmaterials in implant-supported molar crowns. Dent Mater 2017;4:427-433.

2. Villarroel M, Fahl N, De Sousa AM, De Oliveira OB Jr. Direct esthetic restorations based on translucency and opacity of composite resins. J Esthet Restor Dent 2011;23:73-87.

3. Awad D, Stawarczyk B, Liebermann A, Ilie N. Translucency of esthetic dental restorative CAD/CAM materials and composite resins with respect to thickness and surface roughness. J Prosthet Dent 2015; 113:534-540.

4. Kim HK, Kim SH. Effect of the number of coloring liquid applications on the optical properties of monolithic zirconia. Dent Mater 2014;30:229-237.

5. Rinke $S$, Rödiger $M$, Ziebolz D, Schmidt $A K$. Fabrication of zirconia-reinforced lithium silicate ceramic restorations using a complete digital workflow. Case Rep Dent 2015;2015:162-178.

6. Alp G, Subasi MG, Johnston WM, Yilmaz B. Effect of surface treatments and coffee thermocycling on the color and translucency of CAD-CAM monolithic glass-ceramic. J Prosthet Dent 2018;120:263-268. 
7. Al-Thagafi R, Al-Zordk W, Saker S. Influence of surface conditioning protocols on reparability of CAD/CAM zirconia-reinforced lithium silicate ceramic. J Adhes Dent 2016;18:135-141.

8. Belli R, Wendler M, de Ligny D, Cicconi MR, Petschelt A, Peterlik H, Lohbauer U. Chairside CAD/CAM materials. Part 1: measurement of elastic constants and microstructural characterization. Dent Mater 2017;33:84-98.

9. Traini T, Sinjari B, Pascetta R, Serafini N, Perfetti G, Trisi P, Caputi S. The zirconia-reinforced lithium silicate ceramic: lights and shadows of a new material. Dent Mater J 2016;35:748-755.

10. Choi S, Yoon HI, Park EJ. Load-bearing capacity of various CAD/CAM monolithic molar crowns under recommended occlusal thickness and reduced occlusal thickness conditions. J Adv Prosthodont 2017;9:423431.

11. Elsaka SE, Elnaghy AM. Mechanical properties of zirconia reinforced lithium silicate glass-ceramic. Dent Mater 2016;32:908-914.

12. Schwindling FS, Rues S, Schmitter M. Fracture resistance of glazed, full-contour ZLS incisor crowns. J Prosthodont Res 2017;61:344-349.

13. Aboushelib MN, Sleem D. Microtensile bond strength of lithium disilicate ceramics to resin adhesives. J Adhes Dent 2014;16:547-552.

14. Fasbinder DJ. Clinical performance of chairside CAD/CAM restorations. J Am Dent Assoc 2006;137:22-31.

15. Kilinc H, Turgut S. Optical behaviors of esthetic CAD-CAM restorations after different surface finishing and polishing procedures and UV aging: An in vitro study. J Prosthet Dent 2018;120:107-113.

16. Yilmaz C, Korkmaz T, Demirkoprulu H, Ergun G, Ozkan Y. Color stability of glazed and polished dental porcelains. J Prosthodont 2008;17:20-24.

17. Ozarslan MM, Buyukkaplan US, Barutcigil C, Arslan M, Turker N, Barutcigil K . Effects of different surface finishing procedures on the change in surface roughness and color of a polymer infiltrated ceramic network material. J Adv Prosthodont 2016;8:16-20.

18. Fathy SM, Swain MV. In-vitro wear of natural tooth surface opposed with zirconia reinforced lithium silicate glass ceramic after accelerated ageing. Dent Mater 2018;34:551-559.

19. LeSage, B. Finishing and polishing criteria for minimally invasive composite restorations. Gen Dent 2011;59:422-428.

20. Motro PF, Kursoglu P, Kazazoglu E. Effects of different surface treatments on stainability of ceramics. J Prosthet Dent 2012;108:231-237.

21. Vichi A, Fonzar RF, Goracci C, Carrabba M, Ferrari M. Effect of finishing and polishing on roughness and gloss of lithium disilicate and lithium silicate zirconia reinforced glass ceramic for CAD/CAM systems. Oper Dent 2018;43:90-100.

22. Lee YK, Lim BS, Kim CW. Effect of surface conditions on the color of dental resin composites. J Biomed Mater Res 2002;63:657-663.

23. Bollen CML, Papaioannou W, Van Eldere J, Schepers E, Quirynen M, Van Steenberghe D. The influence of abutment surface roughness on plaque accumulation and peri-implant mucositis. Clin Oral Imp Res 1996;7:201-211.

24. Gunal B, Ulusoy MM. Optical properties of contemporary monolithic CAD-CAM restorative materials at different thicknesses. J Esthet Restor Dent 2018;30:434-441.

25. Kurklu D, Azer SS, Yilmaz B, Johnston WM. Porcelain thickness and cement shade effects on the colour and translucency of porcelain veneering materials. J Dent 2013;41:1043-1050.

26. Turgut S, Bagis B. Colour stability of laminate veneers: an in vitro study. J Dent 2011;39:57-64.

27. de Oliveira AL, Botta AC, Campos JA, Garcia PP. Effects of immersion media and repolishing on color stability and superficial morphology of nanofilled composite resin. Microsc Microanal 2014;20:12341239.

28. Sen N, Olcer Y. Mechanical and optical properties of monolithic CAD-CAM restorative materials. J Prosthet Dent. 2018;119:593-599.

29. Commission Internationale de l'Eclairage (CIE). Colorimetry, CIE 015. 3rd ed. Vienna: CIE Central Bureau; 2004.

30. Kim HK, Kim SH, Lee JB, Han JS, Yeo IS, Ha SR. Effect of the amount of thickness reduction on color and translucency of dental monolithic zirconia ceramics. J Adv Prosthodont 2016;8:37-42.

31. Johnston WM, Ma T, Kienle BH. Translucency parameter of colorants for maxillofacial prostheses. Int $\mathbf{J}$ Prosthodont 1995;8:79-86.

32. Alp G, Johnston WM, Yilmaz B. Optical properties and surface roughness of prepolymerized poly (methyl methacrylate) denture base materials. J Prosthet Dent 2019;121:347-352.

33. Bayindir F, Ozbayram O. Effect of number of firings on the color and translucency of ceramic core materials with veneer ceramic of different thicknesses. J Prosthet Dent 2018;119:152-158.

34. Riquieri H, Monteiro JB, Vieagas DC, Campos TMB, Melo RM, Saavedra GSFA. Impact of crystallization firing process on the microstructure and flexural strength of zirconia-reinforced lithium silicate glass-ceramics. Dent Mater 2018;34:1483-1491.

35. Seghi RR, Hewlett ER, Kim J. Visual and instrumental colorimetric assessments of small color differences on translucent dental porcelain. J Dent Res 1989;68:1760-1764.

36. Barizon KTL, Bergeron C, Vargas MA, Qian F. Ceramic materials for porcelain veneers. Part I: correlation between translucency parameters and contrast ratio. J Prosthet Dent 2013;110:397-401.

37. Caprak YO, Turkoglu P, Akgungor G. Does the translucency of novel monolithic CAD/CAM materials 
affect resin cement polymerization with different curing modes? J Prosthodont 2018 Jul 24. [Epub ahead of print]

38. Bahgat SFA, Basheer RR, El Sayed SM. Effect of zirconia addition to lithium disilicate ceramic on translucency and bond strength using different adhesive strategies. Egypt Dent J 2015;61:4519-4533.

39. Steiner R, Beier US, Heiss-Kisielewsky I, Engelmeier R, Dumfahrt H, Dhima M. Adjusting dental ceramics: an in vitro evaluation of the ability of various ceramic polishing kits to mimic glazed dental ceramic surface. J Prosthet Dent 2015;113:616-622.

40. Asai T, Kazama R, Fukushima M, Okiji T. Effect of overglazed and polished surface finishes on the compressive fracture strength of machinable ceramic materials. Dent Mater J 2010;29:661-667.

41. Subası MG, Alp G, Johnston WM, Yilmaz B. Effect of thickness on optical properties of monolithic CAD-CAM ceramics. J Dent 2018;71:38-42.

42. Kou W, Molin M, Sjögren G. Surface roughness of five different dental ceramic core materials after grinding and polishing. J Oral Rehabil 2006;33:117124.

43. Mota EG, Fracasso LM, Spohr AM. The effect of milling and postmilling procedures on the surface roughness of CAD/CAM materials. J Esthet Restor Dent 2017;12:450-458.

44. Yilmaz K, Gonuldas F, Ozturk C. The effect of repeated firings on the color change of dental ceramics using different glazing methods. J Adv Prosthodont 2014;6:427-433.

45. Bolt RA, Bosch JJ, Coops JC. Influence of window size in small-window colour measurement, particularly of teeth. Phys Med Biol 1994;39:1133-1142.

46. Gürdal I, Atay A, Eichberger M, Cal E, Üsümez A, Stawarczyk B. Color change of CAD-CAM materials and composite resin cements after thermocycling. J Prosthet Dent 2018;120:546-552.

47. Gale MS, Darvell BW. Thermal cycling procedures for laboratory testing of dental restorations. J Dent 1999;27:89-99. 